\title{
Pengaruh Pajak Daerah, Retribusi Daerah, dan Lain-Lain PAD yang Sah Terhadap Kinerja Keuangan Daerah
}

\author{
Komang Aryagus Wiguna ${ }^{1}$ \\ I Ketut Jati ${ }^{2}$ \\ ${ }^{1,2}$ Fakultas Ekonomi dan Bisnis Universitas Udayana (Unud), Bali, Indonesia \\ e-mail: komang.aryaguswiguna@gmail.com
}

\begin{abstract}
ABSTRAK
Tujuan dari penelitian ini adalah untuk mengetahui pengaruh pajak daerah, retribusi daerah, dan lain-lain pendapatan asli daerah yang sah terhadap kinerja keuangan daerah pada Pemerintah Provinsi Bali. Penelitian ini menggunakan pendekatan kuantitatif dengan teknik analisis regresi linier berganda. Adapun data pada penelitian ini merupakan data sekunder mengenai PAD Provinsi Bali pada periode tahun 2012-2016. Hasil penelitian menunjukkan bahwa secara parsial, baik pajak daerah, retribusi daerah, maupun lain-lain pendapatan asli daerah yang sah tidak berpengaruh signifikan terhadap kinerja keuangan daerah pada Pemerintah Provinsi Bali. Dapat disarankan bagi peneliti-peneliti selanjutnya untuk mengamati faktor-faktor lain yang dapat mempengaruhi pajak daerah, retribusi daerah dan pendapatan lain-lain yang sah. Beberapa faktor dimaksud seperti jumlah penduduk, PDRB, pengeluaran pemerintah, dan inflasi.
\end{abstract}

Kata kunci: Pajak Daerah, Retribusi Daerah, PAD, kinerja keuangan

\begin{abstract}
The purpose of this study is to determine the effect of local taxes, regional levies, and other legitimate local revenue on regional financial performance in the Bali Provincial Government. This study uses a quantitative approach with multiple linear regression analysis techniques. The data in this study are secondary data regarding the PAD of Bali Province in the period 2012-2016. The results showed that partially, both local taxes, regional levies, as well as other legitimate local revenues did not have a significant effect on regional financial performance in the Bali Provincial Government. It can be suggested for future researchers to observe other factors that can affect local taxes, regional levies and other legitimate income. Some of the factors mentioned are population, GDP, government expenditure and inflation.

Keywords: Regional Tax, Regional Retribution, PAD, financial performance.
\end{abstract}

\section{PENDAHULUAN}

Otonomi Daerah di Indonesia didasarkan pada Undang-Undang Nomor 22 Tahun 1999. Selanjutnya pemerintahan daerah secara khsusus diatur dengan UndangUndang Nomor 32 Tahun 2004 yang selanjutnya diganti dengan Undang-Undang Nomor 23 Tahun 2014 tentang Pemerintahan Daerah. Terkait desentralisasi fiskal, sebelumnya diatur dalam Undang-Undang Nomor 25 Tahun 1999 yang 
diperbaharui dengan Undang-Undang Nomor 33 Tahun 2004 tentang Perimbangan Keuangan Antara Pemerintah Pusat dan Pemerintahan Daerah. Adanya Undang-Undang tersebut telah mengakibatkan pergeseran paradigma penyelenggaraan pemerintah kearah desentralisasi yang ditandai dengan pemberian otonomi yang luas dan nyata kepada daerah. Keberhasilan otonomi daerah tidak terlepas dari kinerja pemerintah daerah dalam mengelola keuangannya secara tertib, taat pada peraturan perundangundangan, efisien, ekonomis, efektif, transparan dan bertanggung jawab. Penilaian kinerja pengelolaan keuangan dilakukan terhadap APBD yang dilakukan pemerintah daerah yang wajib menyampaikan laporan pertanggungjawaban keuangan daerahnya untuk dinilai apakah pemerintah daerah berhasil menjalankan tugasnya dengan baik atau tidak.

Diterapkannya otonomi daerah, baik pada tingkat provinsi maupun kabupaten/kota, memberikan keleluasaan kepada pemerintah daerah setempat untuk menggali potensi sumber keuangan di daerahnya sekaligus dapat menentukan alokasi sumber daya ke belanja daerah sesuai dengan kebutuhan dan aspirasi masyarakat di daerahnya. Semakin banyak sumber-sumber keuangan yang berhasil digali di suatu daerah, maka hal ini akan meningkatkan pendapatan daerah yang semestinya diikuti dengan meningkatnya pertumbuhan ekonomi di daerah tersebut. Pertumbuhan ekonomi yang tinggi mendorong pemerintah daerah untuk melakukan pembangunan daerah yang direalisasikan dalam bentuk pengadaan fasilitas, infrastruktur dan sarana prasarana yang ditujukan untuk kepentingan publik. Agar pemerintah daerah mampu menyediakan pelayanan 
publik yang memadai, disinilah diperlukan alokasi belanja modal yang lebih tinggi.

Kinerja keuangan pemerintah daerah dikelola melalui manajemen keuangan daerah. Manajemen keuangan daerah adalah pengorganisasian dan pengelolaan sumber-sumber daya atau kekayaan yang ada pada suatu daerah untuk mencapai tujuan yang dikehendaki daerah tersebut. Kemampuan daerah untuk mencapai tujuan tersebut disebut kinerja pemerintah daerah. Sehubungan dengan efektifnya otonomi daerah maka kinerja pemerintah daerah dalam keuangan daerah sangat dituntut untuk membiayai aktivitas daerah melalui penggalian kekayaan asli daerah. Kinerja keuangan sendiri diukur dengan menggunakan berbagai rasio. Salah satunya menggunakan tingkat desentralisasi fiskal, yaitu pendapatan daerah per total penerimaan daerah, atau menggunakan rasio kemandirian, yaitu total pendapatan asli daerah per total bantuan pemerintah pusat dan pinjaman.

Setiap daerah otonom dalam hal ini provinsi maupun kabupaten/kota di Indonesia, memiliki sumber daya alam dan potensi ekonomi yang bervariasi, sehingga jika dimanfaatkan dengan optimal maka akan mampu berkontribusi lebih signifikan, dalam penerimaan pendapatan asli daerah dengan tujuan memberikan kontribusi yang signifikan bagi penerimaan pendapatan asli daerah, yang pada tujuannya akan memberikan manfaat dalam pembangunan daerah (Poulson \& Kaplan, 2008). Dalam rangka penyelenggaraan pembangunan dan menunjang pemerintahan daerahnya, pemerintah daerah berhak mengenakan 
pemungutan pajak daerah dan retribusi daerah kepada seluruh warga masyarakatnya (Tjip, 2012).

Undang-Undang Nomor 28 Tahun 2009 tentang Pajak Daerah dan Retribusi Daerah mencantumkan definisi pajak daerah adalah kontribusi wajib kepada daerah yang terutang oleh orang pribadi atau badan yang bersifat memaksa berdasarkan undang-undang, dengan tidak mendapatkan imbalan secara langsung dan digunakan untuk keperluan daerah bagi sebesar-besarnya kemakmuran rakyat. Pajak daerah yang merupakan salah satu sumber penting dan utama dari Pendapatan Asli Daerah (PAD) yang akan sangat berpengaruh pada kinerja keuangan pemerintah daerah. Jika pendapatan pajak daerah suatu daerah tinggi atau sesuai target yang ditetapkan, maka hal ini menunjukkan kinerja keuangan yang bagus dari daerah tersebut.

Kendala yang dihadapi pemerintah dalam pelaksanaan otonomi daerah adalah tingkat kesiapan keuangan yang berbeda pada setiap daerah. Kebijakan otonomi daerah adalah kebijakan yang menguntungkan daerah-daerah yang mempunyai sumber daya potensial namun bagi daerah yang kurang memiliki sumber daya potensial menganggap kebijakan otonomi daerah merupakan kebijakan yang tidak menguntungkan (Norregaard, 2013). Penelitian Aragon (2009) menjelaskan bahwa pemerintah daerah memperoleh dana paling besar dari pajak daerah dan pemerintah pusat. 
Retribusi daerah menurut Undang-Undang Nomor 28 Tahun 2009 adalah pungutan daerah sebagai pembayaran atas jasa atau pemberian izin tertentu yang khusus disediakan dan/atau diberikan oleh Pemerintah Daerah untuk kepentingan pribadi atau badan. Berbeda dengan pajak pusat seperti Pajak Penghasilan dan Pajak Pertambahan Nilai yang dikelola oleh Direktorat Jenderal Pajak, jenis pos retribusi daerah dapat dikelompokkan menjadi Retribusi Jasa Umum, Retribusi Jasa usaha, dan Retribusi Perizinan.

Retribusi daerah yang merupakan salah satu sumber PAD yang paling besar ini juga menjadi salah satu indikator penting untuk mengetahui dan mengevaluasi kinerja keuangan pemerintah daerah.Seperti halnya pajak daerah, apabila retribusi daerah suatu daerah tinggi atau sesuaitarget, maka hal ini menunjukkan kinerja keuangan yang bagus dari daerah tersebut.

Undang-Undang Nomor 33 Tahun 2004 tentang Perimbangan Keuangan Antara Pemerintah Pusat dan Pemerintahan Daerah menyebutkan bahwa dana perimbangan adalah dana yang bersumber dari pendapatan APBN yang dialokasikan kepada daerah untuk mendanai kebutuhan daerah dalam rangka desentralisasi.

Penetapan otonomi daerah telah memberikan kebebasan bagi pemerintah daerah untuk berinisiatif mengatur dan memaksimalkan sumber daya daerah, hal itu menjadi dasar daerah untuk bisa bergerak sesuai dengan kebutuhan masingmasing. Otonomi daerah juga dapat memberikan dampak yang positif bagi perkembangan ekonomi rakyat hal ini diakibatkan karena adanya harapan baru untuk memperoleh kebijakan daerah demi kesejahteraan masyarakat. 
Keuntungannya dapat lebih giat lagi untuk melakukan pembenahan dan pembangunan fasilitas umum dari hasil pemungutan pajak daerahnya. Namun pelaksanaan pembangunan daerah sering terkendala keterbatasan dana akibat pemberlakuan Undang-Undang Otonomi Daerah untuk aktif menggali sumbersumber pendapatan daerah yang potensial dan meminimalkan ketergantungan bantuan pusat (Hoque \& Adams, 2008).

Undang-Undang Nomor 33 Tahun 2004 tentang Perimbangan Keuangan Antara Pemerintah Pusat dan Pemerintahan Daerah juga menyebutkan bahwa dana perimbangan terdiri atas Dana bagi hasil, Dana alokasi umum dan Dana alokasi khusus. Berdasarkan Undang-Undang Nomor 33 Tahun 2004 tentang Perimbangan Keuangan Antara Pemerintah Pusat dan Pemerintah Daerah, Dana Perimbangan yang meliputi Dana Bagi Hasil Pajak dan Bukan Pajak serta DAU dan DAK merupakan dana transfer dari pemerintah pusat kepada pemeritah daerah dengan tujuan untuk membiayai kelebihan belanja daerah. Dana Perimbangan mempengaruhi kinerja keuangan pemerintah daerah, yaitu dana yang diterima dari pemerintah pusat akan memperlihatkan semakin kuat pemerintah daerah bergantung kepada pemerintah pusat untuk memenuhi kebutuhan daerahnya. Sehingga akan membuat kinerja keuangan pemerintah daerah menurun (Julitawati et al., 2012). 
Penelitian terdahulu menyimpulkan bahwa secara parsial, pajak dan retribusi daerah tidak berpengaruh signifikan terhadap kinerja keuangan, berbeda dengan dana perimbangan yang berpengaruh signifikan terhadap kinerja keuangan. Dari uraian diatas, terlihat jelas bahwa ciri utama kemampuan suatu daerah adalah terletak pada kemampuan keuangan daerah artinya daerah otonomi harus memiliki kewenangan dan kemampuan untuk menggali sumber-sumber keuangan sendiri. Perbedaan penelitian ini dengan penelitian-penelitian sebelumnya adalah penelitian ini menspesifikasikan PAD pada Pajak Daerah, Retribusi Daerah, dan Lain-Lain Pendapatan Asli Daerah yang Sah, karena pada tiga variabel ini banyak ditemukan adanya masalah dalam implikasinya dalam pemerintahan. Selain itu, studi empiris penelitian ini berada pada Pemerintah Provinsi Bali.

Pajak daerah, retribusi daerah, dan lain-lain pendapatan asli daerah yang sah pada Pemerintah Provinsi Bali sesuai data dari Badan Pengelolaan Keuangan dan Aset (BPKAD) Provinsi Bali periode tahun 2012-2016 cenderung fluktuatif. Lain-Lain Pendapatan Asli Daerah yang Sah cenderung mengalami peningkatan, namun Pajak Daerah dan Retribusi Daerah sempat mengalami penurunan tahun 2013, demikian halnya retribusi daerah juga sempat mengalami penurunan pada tahun 2016. Adapun data mengenai nilai dan fluktuasi Pajak Daerah, Retribusi Daerah, dan Lain-Lain Pendapatan Asli Daerah yang Sah pada APBD Provinsi Bali periode tahun 2012-2016 disajikan pada Tabel 1. 
Tabel 1.

Pajak Daerah, Retribusi Daerah, dan Lain-Lain Pendapatan Asli Daerah yang Sah Periode Tahun 2012-2016 (dalam Juta Rupiah)

\begin{tabular}{lccccccc}
\hline & & \multicolumn{5}{c}{ Total Penerimaan Retribusi } \\
No & $\begin{array}{c}\text { Tahun } \\
\text { Anggaran }\end{array}$ & $\begin{array}{c}\text { Pajak Daerah } \\
\text { (Juta Rp.) }\end{array}$ & $\%$ & $\begin{array}{c}\text { Retribusi } \\
\text { Daerah } \\
\text { (Juta Rp.) }\end{array}$ & $\%$ & $\begin{array}{c}\text { Lain-lain } \\
\text { Pendapatan Asli } \\
\text { Daerah yang Sah } \\
\text { (Juta Rp.) }\end{array}$ & $\%$ \\
\hline 1. & 2012 & $1.692 .123,674$ & - & $48.317,692$ & - & $47.814,860$ & - \\
2. & 2013 & $2.202 .392,550$ & 0,30 & $50.545,903$ & 0,05 & $189.465,281$ & 2,96 \\
3. & 2014 & $2.911 .541,391$ & 0,32 & $71.324,624$ & 0,41 & $233.037,046$ & 0,23 \\
4. & 2015 & $2.571 .035,790$ & $-0,12$ & $59.863,688$ & $-0,16$ & $304.959,679$ & 0,31 \\
5. & 2016 & $2.593 .093,540$ & 0,01 & $63.858,566$ & 0,07 & $211.832,476$ & $-0,31$ \\
\hline \multicolumn{5}{l}{ Sumber: BPKAD Provinsi Bali, 2018 }
\end{tabular}

Fluktuasi sebagaimana ditampilkan pada Tabel 1 menunjukkan bahwa kinerja keuangan pemerintah daerah Provinsi Bali belum stabil dan belum menunjukkan kinerja yang baik. Pentingnya penelitian ini dilakukan adalah untuk melihat seberapa besar Pengaruh Pajak Daerah, Retribusi Daerah, dan Lain-Lain Pendapatan Asli Daerah yang Sah Terhadap Kinerja Keuangan Daerah pada Pemerintah Provinsi Bali.

Anggaran Pendapatan dan Belanja Daerah (APBD) adalah suatu rencana kerja pemerintah yang dinyatakan secara kuantitatif, biasanya dalam satuan moneter yang mencerminkan sumbersumber penerimaan daerah dan pengeluaran untuk membiayai kegiatan dan proyek daerah dalam kurun waktu satu tahun anggaran. Pada hakikatnya anggaran daerah (APBD) merupakan salah satu alat untuk meningkatkan pelayanan publik dan kesejahteraan masyarakat sesuai dengan tujuan otonomi daerah yang luas, nyata dan bertanggungjawab.

APBD terdiri dari komponen pendapatan, belanja, dan pembiayaa. Pendapatan dibagi menjadi 3 (tiga) kategori yaitu Pendapatan Asli Daerah (PAD), Dana Perimbangan, dan Lain-lain Pendapatan Daerah yang Sah. Selanjutnya, Belanja digolongkan menjadi 2 (dua) kategori, yakni Belanja Tidak Langsung dan 
Belanja Langsung. Belanja tidak langsung terdiri dari belanja pegawai, belanja subsidi, belanja hibah, belanja bantuan sosial, belanja bagi hasil, belanja bantuan keuangan, dan belanja tidak terduga. Sedangka belanja langsung terdiri dari belanja pegawai, belanja barang dan jasa, serta belanja modal.

Pembiayaan seperti sudah dikatakan di atas, adalah sumber-sumber penerimaan dan pengeluaran daerah yang dimaksudkan untuk menutup defisit anggaran atau sebagai alokasi surplus anggaran. Pembiayaan dikelompokkan menurut sumber-sumber pembiayaan, yaitu: sumber penerimaan daerah dan sumber pengeluaran daerah. Sumber pembiayaan berupa penerimaan daerah adalah: sisa lebih anggaran tahun lalu, penerimaan pinjaman dan obligasi, hasil penjualan aset daerah yang dipisahkan, dan transfer dari dana cadangan. Sumber pembiayaan berupa pengeluaran daerah terdiri atas: pembayaran utang pokok yang telah jatuh tempo, penyertaan modal, transfer ke dana cadangan, dan sisa lebih anggaran tahun sekarang.

Menurut Halim, (2007:24) kinerja keuangan pemerintah daerah merupakan salah satu ukuran yang dapat digunakan untuk melihat kemampuan daerah dalam menjalankan otonomi daerah. Selanjutnya pengukuran kinerja diartikan sebagai suatu indikator keuangan atau non keuangan dari suatu pekerjaan yang dilaksanakan atau hasil yang dicapai dari suatu aktivitas suatu proses atau suatu unit organisasi. Pengukuran kinerja merupakan wujud akuntabilitas di mana penilaian yang lebih tinggi menjadi tuntutan yang harus dipenuhi, data pengukuran kinerja dapat menjadi peningkatan program selanjutnya. 
Pengukuran kinerja keuangan salah satu ukuran yang dapat digunakan untuk melihat kemampuan daerah dalam menjalankan otonomi daerah, pencapaian prestasi atau keberhasilan pemerintah daerah dalam memperoleh sumber-sumber keuangan daerah dan bagaimana mengalokasikan untuk melaksanakan berbagai macam program dan kegiatan pemerintah daerah yang dapat dilihat dari pencapaian anggaran daerah dengan tingkat realisasinya.

Pajak daerah merupakan komponen utama dari Pendapatan Asli Daerah. Diharapkan dengan adanya peningkatan nilai PAD juga akan berpengaruh terhadap kinerja keuangan suatu daerah. Sebagaimana hasil penelitian sebelumnya dari (Nuzulistyan et al., 2017) yang menyebutkan bahwa pajak daerah berpengaruh positif dan signifikan terhadap pendapatan asli daerah Provinsi Jawa Tengah, maka dapat dirumuskan hipotesis penelitian sebagai berikut.

$\mathrm{H}_{1}$ : Pajak daerah berpengaruh positif pada kinerja keuangan daerah Pemerintah Provinsi Bali periode tahun 2012-2016.

Retribusi daerah juga merupakan komponen penting PAD yang terus dikembangkan oleh pemerintah daerah. Berdasarkan tinjauan penelitian sebelumnya, yaitu penelitian Mukarramah (2017) bahwa retribusi daerah ternyata tidak berpengaruh signifikan terhadap kemandirian keuangan daerah di lima kabupaten/kota Provinsi Jawa Barat Tahun 2008-2014, maka dapat dirumuskan hipotesis penelitian sebagai berikut:

$\mathrm{H}_{2}$ : Retribusi daerah berpengaruh positif pada kinerja keuangan daerah Pemerintah Provinsi Bali periode tahun 2012-2016. 
Komponen terakhir dari PAD yang juga menunjukkan kemampuan daerah menggali potensi pendapatannya adalah Lain-lain Pendapatan Asli Daerah yang Sah. Hasil penelitian sebelumnya dari Nuzulistyan et al. (2017) bahwa lain-lain pendapatan asli daerah yang sah berpengaruh positif dan signifikan terhadap pendapatan asli daerah Provinsi Jawa Tengah. Berdasarkan tinjauan tersebut, maka dapat dirumuskan hipotesis penelitian sebagai berikut:

$\mathrm{H}_{3}$ : Lain-lain pendapatan asli daerah yang sah berpengaruh positif pada kinerja keuangan daerah Pemerintah Provinsi Bali periode tahun 2012-2016.

\section{METODE PENELITIAN}

Penelitian ini berlokasi di Provinsi Bali. Penelitian ini dilaksanakan dari bulan Juli 2017 sampai dengan September 2017. Penelitian ini dilaksanakan dalam beberapa tahap yang diawali dengan penelitian pendahuluan yang dilaksanakan pada bulan Juni 2017. Sedangkan penelitian lanjutan dilaksanakan pada saat penyusunan skripsi dengan jangka waktu kurang lebih 3 bulan dari bulan Juli sampai dengan September 2017.

Populasi dalam penelitian ini adalah seluruh dokumen Realisasi Anggaran Pendapatan dan Belanja Daerah Pemerintah Provinsi Bali dari tahun 2012 sampai dengan 2016. Sampel dalam penelitian ini menggunakan teknik penarikan sampel secara penuh (total sampling) dimana semua jumlah populasi dijadikan sampel. Jadi sampel dalam penelitian ini adalah semua dokumen Realisasi Anggaran Pendapatan dan Belanja Daerah Provinsi Bali dari tahun 2012 sampai dengan 2016. 
Untuk menguji pengaruh pajak daerah, retribusi daerah, dan lain-lain pendapatan asli daerah yang sah terhadap kinerja keuangan, peneliti menggunakan uji regresi linear multiple. Bentuk umum persamaan ini yaitu:

$$
\hat{Y}=a+\beta_{1} X_{1}+\beta_{2} X_{2}+\beta_{3} X_{3}+e
$$

Keterangan:

\begin{tabular}{|c|c|}
\hline$\hat{\mathrm{Y}}$ & $=$ Kinerja keuangan daerah \\
\hline$a$ & $=$ Konstanta \\
\hline$\beta_{1}, \beta_{2}, \beta_{3}$ & $=$ Koefisien regresi \\
\hline $\mathrm{X}_{1}$ & $=$ Pajak daerah \\
\hline $\mathrm{X}_{2}$ & $=$ Retribusi daerah \\
\hline $\mathrm{X}_{3}$ & $\begin{array}{l}\text { = Lain-lain pendapatan asli daerah yang sah } \\
\text { - Frror }\end{array}$ \\
\hline
\end{tabular}

\section{HASIL DAN PEMBAHASAN}

Uji normalitas dalam penelitian ini digunakan untuk melakukan uji persyaratan uji asumsi klasik atau uji analisis data sebelum data dan harus diuji kenormalan disribusi suatu data tersebut. Uji normalitas memiliki dua dasar dalam pengambilan keputusan yaitu jika nilai signifikansi lebih besar dari 0,05 maka data tersebut berdistribusi normal, dan jika nilai signifikansi berada lebih kecil dari 0,05 maka data tersebut bersifat distribusi tidak normal. Uji normalitas untuk penelitian ini, penulis memilih uji normalitas Kolmogorov-Smirnov Test.

Tabel 2.

Output Uji Normalitas

\begin{tabular}{|c|c|c|c|c|c|}
\hline \multirow{2}{*}{\multicolumn{2}{|c|}{ Uraian }} & \multicolumn{4}{|c|}{ Kode Variabel } \\
\hline & & $\mathrm{X} 1$ & $\mathrm{X} 2$ & $\mathrm{X} 3$ & $\mathrm{Y}$ \\
\hline $\mathrm{N}$ & & 5 & 5 & 5 & 5 \\
\hline Normal & Mean & $2.394 .037,38$ & $58.782,09$ & $197.421,86$ & $3.009 .157,90$ \\
\hline Parameters ${ }^{\mathrm{a}, \mathrm{b}}$ & Std. Deviation & $465.878,95$ & $9.507,81$ & $94.188,70$ & $996.775,51$ \\
\hline \multirow{3}{*}{$\begin{array}{l}\text { Most Extreme } \\
\text { Differences }\end{array}$} & Absolute & 0,248 & 0,207 & 0,266 & 0,287 \\
\hline & Positive & 0,135 & 0,207 & 0,153 & 0,287 \\
\hline & Negative & $-0,248$ & $-0,145$ & $-0,266$ & $-0,141$ \\
\hline \multirow{2}{*}{\multicolumn{2}{|c|}{$\begin{array}{l}\text { Test Statistic } \\
\text { Asymp. Sig. (2-tailed) }\end{array}$}} & 0,248 & 0,207 & 0,266 & 0,287 \\
\hline & & $0,200^{\mathrm{c}, \mathrm{d}}$ & $0,200^{\mathrm{c}, \mathrm{d}}$ & $0,200^{\mathrm{c}, \mathrm{d}}$ & $0,200^{\mathrm{c}, \mathrm{d}}$ \\
\hline
\end{tabular}


Asymp.Sig yang ditunjukkan oleh Tabel 2 merupakan hasil dari uji normalitas yaitu sebesar 0.200 nilai ini lebih besar dari 0.05 , maka dapat disimpulkan bahwa data yang digunakan dalam penelitian bersifat normal.

Uji Multikolinearitas penelitian ini digunakan untuk menguji model regresi terhadap variabel independen.

Tabel 3.

Output Uji Multikolinearitas

\begin{tabular}{|c|c|c|c|c|c|c|c|}
\hline \multirow{2}{*}{$\begin{array}{c}\text { Variabel } \\
\text { Independen }\end{array}$} & \multicolumn{2}{|c|}{ Unstandardized Coefficients } & \multirow{2}{*}{$\begin{array}{c}\text { Standardized } \\
\text { Coefficients } \\
\text { Beta } \\
\end{array}$} & \multirow[t]{2}{*}{$\mathrm{t}$} & \multirow[t]{2}{*}{ Sig. } & \multicolumn{2}{|c|}{$\begin{array}{c}\text { Collinearity } \\
\text { Statistics }\end{array}$} \\
\hline & $\mathrm{B}$ & Std. Error & & & & Tolerance & VIF \\
\hline Konstanta & $2.806 .534,604^{-}$ & $1.830 .075,070$ & & 1,534 & 0,368 & & \\
\hline $\begin{array}{l}\text { Pajak } \\
\text { Daerah }\left(\mathrm{X}_{1}\right)\end{array}$ & 2,799 & 3,972 & 1,308 & 0,705 & 0,609 & 0,022 & 45,803 \\
\hline $\begin{array}{l}\text { Retribusi } \\
\text { Daerah }\left(\mathrm{X}_{2}\right) \\
\text { Lain-lain }\end{array}$ & 2,110 & 137,637 & 0,020 & 0,015 & 0,990 & 0,044 & 22,912 \\
\hline $\begin{array}{l}\text { Pendapatan } \\
\text { Asli Daerah } \\
\left(\mathrm{X}_{3}\right)\end{array}$ & $-5,110$ & 8,807 & $-0,483$ & 0,580 & 0,665 & 0,109 & 9,207 \\
\hline
\end{tabular}

Sumber: Data diolah, 2018

Hasil output terhadap uji Multikolinearitas ditunjukkan pada Tabel 3 Berdasarkan output tersebut dapat dilihan nilai Tolarance terhadap variabel $\mathrm{X}_{1}$, $X_{2}$, dan $X_{3}$, secara berurutan, yaitu 0,$022 ; 0,044$; dan 0,109 . Semua nilai Tolarance tersebut lebih kecil atau mendekati dari 0,10. Nilai VIF untuk masingmasing variabel $X_{1}, X_{2}$, dan $X_{3}$, adalah 45,$803 ; 22,912$; dan 9,207 , data tersebut lebih besar atau mendekati dari 10,00. Berdasarkan hasil dari uji Multikolinearitas, untuk nilai Tolarance dan VIF maka dapat ditentukan bahwa tidak terjadi multikolinearitas terhadap data yang diuji atau antar variabel bebas.

Uji autokorelasi memiliki tujuan untuk menguji apakah model regresi linear memiliki korelasi antara kesalahan pengganggu pada periode $\mathrm{t}$ dengan 
kesalahan pengganggu pada periode t-1 (sebelumnya). Jika terjadi korelasi, maka dinamakan ada problem autokorelasi terhadap data yang diteliti.

Tabel 4.

Output Uji Autokorelasi

\begin{tabular}{ccccc}
\hline $\mathrm{R}$ & $\mathrm{R}$ Square & Adjusted R Square & Std. Error of the Estimate & $\begin{array}{c}\text { Durbin- } \\
\text { Watson }\end{array}$ \\
\hline 0,962 & 0,925 & 0,699 & $546.779,098$ & 1,297 \\
\hline Sumber: Data diolah, 2018 & & &
\end{tabular}

Berdasarkan output Uji autokorelasi yang ditunjukkan pada Tabel 4 dapat diketahui bahwa nilai dari Uji Autokorelasi Durbin Watson sebesar 1,297, nilai tersebut selanjutnya akan dibandingkan dengan nilai tabel signifikan untuk mengetahui nilai du.

Uji Heterokedastisitas atau Uji Asumsi Klasik dalam penelitian ini untuk menguji ketidaksamaan variance dari residual terhadap pengamatan yang ada.

Tabel 5.

Output Uji Heteroskedastisitas

\begin{tabular}{lrrrrr}
\hline \multicolumn{1}{c}{ Variabel Independen } & \multicolumn{2}{c}{ Unstandardized Coefficients } & $\begin{array}{c}\text { Standardized } \\
\text { Coefficients } \\
\text { Beta }\end{array}$ & $\mathrm{t}$ & Sig. \\
\hline Konstanta & \multicolumn{1}{c}{$\mathrm{B}$} & Std. Error & & \\
Pajak Daerah $\left(\mathrm{X}_{1}\right)$ & $-2.806 .534,604$ & $1.830 .075,070$ & & $-1,534$ & 0,368 \\
Retribusi Daerah $\left(\mathrm{X}_{2}\right)$ & 2,799 & 3,972 & 1,308 & 0,705 & 0,609 \\
Lain-lain Pendapatan & 2,110 & 137,637 & 0,020 & 0,015 & 0,990 \\
Asli Daerah $\left(\mathrm{X}_{3}\right)$ & $-5,110$ & 8,807 & $-0,483$ & $-0,580$ & 0,665 \\
\hline Sumber: Data diolah, 2018 & & & & &
\end{tabular}

Hasil output yang terdapat pada Tabel 5 menunjukkan bahwa hasil signifikansi pada masing-masing variabel lebih dari 0.05. Variabel $\mathrm{X}_{1}$ (Pajak Daerah) memiliki nilai signifikansi 0,609 ; variabel $\mathrm{X}_{2}$ (Retribusi Daerah) memiliki nilai 0,990; dan variabel $\mathrm{X}_{3}$ (Lain-lain Pendapatan Daerah yang Sah) memiliki nilai signifikansi sebesar 0,665. Berdasarkan hasil dari uji 
heteroskedastisitas terhadap ketiga variabel tersebut, maka tidak terjadi heteroskedastisitas pada Pajak Daerah, Retribusi Daerah, dan Lain-Lain Pendapatan Daerah yang Sah karena nilai signifikansi yang dihasilkan lebih besar dari 0,05 .

Deskripsi data hasil penelitian berisi penjelasan mengenai banyaknya jumlah sampel yang diteliti, nilai minimum dan nilai maksimum, standar deviasi dan rata-rata dari masing-masing variabel sebagaimana disajikan pada Tabel 6.

Tabel 6.

Output Descriptive Statistics

\begin{tabular}{|c|c|c|c|c|}
\hline Variabel & $\begin{array}{c}\text { Nilai } \\
\text { Minimum } \\
\text { (Juta Rp.) }\end{array}$ & $\begin{array}{c}\text { Nilai } \\
\text { Maksimum } \\
\text { (Juta Rp.) }\end{array}$ & $\begin{array}{l}\text { Rata-rata } \\
\text { (Juta Rp.) }\end{array}$ & $\begin{array}{c}\text { Standar } \\
\text { Deviasi } \\
\text { (Juta Rp.) }\end{array}$ \\
\hline Pajak Daerah $\left(\mathrm{X}_{1}\right)$ & $1.692 .123,67$ & $2.911 .541,39$ & $2.394 .037,38$ & $465.878,95$ \\
\hline Retribusi Daerah $\left(\mathrm{X}_{2}\right)$ & $48.317,69$ & $71.324,62$ & $58.782,09$ & $9.507,81$ \\
\hline $\begin{array}{l}\text { Lain-lain Pendapatan Asli } \\
\text { Daerah yang } \mathrm{Sah}\left(\mathrm{X}_{3}\right)\end{array}$ & $47.814,86$ & $304.959,68$ & $197.421,86$ & $94.188,70$ \\
\hline $\begin{array}{l}\text { Kinera Keuangan Daerah } \\
\text { (Y) }\end{array}$ & $1.864 .569,73$ & $4.568 .802,88$ & $3.009 .157,90$ & $996.775,51$ \\
\hline
\end{tabular}

Tabel 6 menunjukkan kondisi pajak daerah, retribusi daerah, dan lain-lain pendapatan asli daerah yang sah selama periode pengamatan (Tahun 2012 2016). Terkait pajak daerah $\left(X_{1}\right)$, dari lima periode sampel pengamatan, ternyata diketahui bahwa pajak daerah Pemerintah Provinsi Bali yang paling rendah adalah tahun 2012 sebesar Rp1,6 Triliun. Sedangkan pajak daerah tertinggi sebesar Rp2,9 Triliun yaitu pada tahun 2014. Rata-rata pajak daerah provinsi Bali pada tahun 2012-2016 adalah sebesar Rp2,3 Triliun dengan standar deviasi sebesar Rp0,46 Triliun. 
Terkait dengan retribusi daerah $\left(\mathrm{X}_{2}\right)$, sesuai Tabel 6 diketahui bahwa retribusi daerah terendah di Provinsi Bali yaitu sebesar Rp48,3 Milyar pada tahun 2012, dan tertinggi sebesar Rp71,3 Milyar yaitu pada tahun 2014. Sedangkan ratarata Retribusi Daerah Provinsi Bali selama tahun 2012-2016 sebesar Rp58,7 Milyar dengan standar deviasi sebesar Rp0,95 Milyar.

Tabel 6 juga menunjukkan kondisi Lain-lain Pendapatan Asli Daerah yang Sah. Nilai maksimum dan minimum untuk lain-lain pendapatan asli daerah yang sah secara berurutan adalah Rp47 Milyar dan Rp304 Milyar. Nilai minimum dan maksimum tersebut berada pada tahun 2012 dan tahun 2015. Rata-rata Lain-lain Pendapatan Asli Daerah yang Sah adalah sebesar Rp197,4 Milyar dengan standar deviasi Rp94,1 Milyar.

Uji Linier Berganda dalam penelitian ini berguna untuk melakukan pengujian terhadap pengaruh dua atau lebih variabel bebas dan mencari hubungan fungsionalnya.

Tabel 7.

Output Variable Entered

\begin{tabular}{lcc}
\hline \multicolumn{1}{c}{ Variables Entered } & Variables Removed & Method \\
\hline Pajak Daerah $\left(\mathrm{X}_{1}\right)$ & - & Enter \\
Retribusi Daerah $\left(\mathrm{X}_{2}\right)$ & & \\
Lain-lain Pendapatan Asli & & \\
Daerah $\left(\mathrm{X}_{3}\right)$ &
\end{tabular}

Metode yang digunakan dalam uji liner berganda adalah metode Enter, variabel yang dimasukan adalah $\mathrm{X}_{1}$ (Pajak Daerah), $\mathrm{X}_{2}$ (Retribusi Daerah), dan $\mathrm{X}_{3}$ (Lain-lain Pendapatan Asli Daerah yang Sah). 
Tabel 8.

Output Model Summary

\begin{tabular}{cccc}
\hline $\mathrm{R}$ & R Square & Adjusted R Square & Std. Error of the Estimate \\
\hline 0,962 & 0,925 & 0,699 & $546.779,09861$ \\
\hline Sumber: Data diolah, 2018 & &
\end{tabular}

Besarnya nilai korelasi pada Tabel 8 menjelaskan tentang hubungan pajak daerah, retribusi daerah, dan lain-lain pendapatan asli daerah yang sah terhadap kinerja keuangan Pemerintah Provinsi Bali yaitu sebesar 0.983 dan besar $R$ Square (koefisien determinasi) sebesar 0.925.

Tabel 9.

Output Anova

\begin{tabular}{lrrrrr}
\hline & Sum of Squares & df & Mean Square & F & \multicolumn{1}{c}{ Sig. } \\
\hline Regression & $3.675 .278 .335 .522,452$ & 3 & $1.225 .092 .778 .507,484$ & 4,098 & $0,345^{\text {b }}$ \\
Residual & $298.967 .382 .680,901$ & 1 & $298.967 .382 .680,901$ & & \\
Total & $3.974 .245 .718 .203,353$ & 4 & & & \\
\hline
\end{tabular}

Sumber: Data diolah, 2018

Berdasarkan Tabel 9 untuk mengetahui pengaruh Pajak Daerah $\left(\mathrm{X}_{1}\right)$, Retribusi Daerah $\left(\mathrm{X}_{2}\right)$, dan Lain-lain Pendapatan Daerah yang Sah $\left(\mathrm{X}_{3}\right)$ terhadap Kinerja Keuangan Daerah $(\mathrm{Y})$ dengan nilai $\mathrm{F}_{\text {hitung }}$ adalah sebesar 4,098 dengan tingkat signifikansi sebesar 0,345.

Selanjutnya perlu dilakukan evaluasi terhadap konstanta, nilai $t_{\text {hitung, dan }}$ signifikansi pada hubungan antara masing-masing variabel independen terhadap variabel dependen. Adapun hasil analisis regresi linier berganda untuk evaluasi dimaksud ditampilkan pada Tabel 10 berikut. 
Tabel 10. Hasil Output

\begin{tabular}{|c|c|c|c|c|c|}
\hline \multirow{2}{*}{ Variabel Independen } & \multicolumn{2}{|c|}{ Unstandardized Coefficients } & \multirow{2}{*}{$\begin{array}{c}\text { Standardized } \\
\text { Coefficients } \\
\text { Beta }\end{array}$} & \multirow{2}{*}{$\mathrm{t}$} & \multirow{2}{*}{ Sig. } \\
\hline & B & Std. Error & & & \\
\hline Konstanta & $-2.806 .534,604$ & $1.830 .075,070$ & & $-1,534$ & 0,368 \\
\hline Pajak Daerah $\left(\mathrm{X}_{1}\right)$ & 2,799 & 3,972 & 1,308 & 0,705 & 0,609 \\
\hline Retribusi Daerah $\left(\mathrm{X}_{2}\right)$ & 2,110 & 137,637 & 0,020 & 0,015 & 0,990 \\
\hline $\begin{array}{l}\text { Lain-lain Pendapatan } \\
\text { Asli Daerah }\left(\mathrm{X}_{3}\right)\end{array}$ & $-5,110$ & 8,807 & $-0,483$ & $-0,580$ & 0,665 \\
\hline
\end{tabular}

Pada Tabel 10 diketahui $\mathrm{t}_{\text {hitung }}$ untuk masing-masing variabel adalah 0,705; 0,015; dan -0,580. Pada penelitian ini $\mathrm{t}_{\text {tabel }}$ yaitu sebesar 3,182. Karena $\mathrm{t}_{\text {tabel }}$ lebih besar dari $t_{\text {hitung, }}$, maka pengaruh antara variabel pajak daerah, retribusi daerah, dan lain-lain pendapatan asli daerah yang sah terhadap kinerja keuangan daerah tidak signifikan.

Hasil penelitian ini menunjukan bahwa pajak daerah berpengaruh tidak signifikan terhadap kinerja keuangan daerah pada Pemerintah Provinsi Bali berdasarkan pada Tabel 10. Hal ini tidak sesuai dengan hasil penelitian sebelumnya dari Nuzulistyan et al. (2017) bahwa pajak daerah berpengaruh positif dan signifikan terhadap pendapatan asli daerah Provinsi Jawa Tengah. Demikian juga hasil penelitian Vamiagustin et al. (2014) yang meneliti pengaruh pajak daerah terhadap pendapatan asli daerah (studi kasus pada Dinas Pendapatan Kota Batu Tahun 2010-2012), menunjukkan bahwa berbagai jenis pajak daerah secara simultan berpengaruh positif dan signifikan terhadap pendapatan asli daerah. Hal ini dipertegas kembali oleh penelitian Putri \& Rahayu (2015) bahwa pajak daerah berpengaruh positif dan signifikan terhadap pendapatan asli daerah pada Pemerintah Daerah Kabupaten Cirebon tahun anggaran 2010-2014. 
Hasil penelitian ini menunjukan bahawa kontribusi pajak daerah terhadap Pendapatan Asli Daerah masih sangat kecil. Manajemen perpajakan daerah harus mampu menciptakan sistem pemungutan yang ekonomis, efisien, dan efektif. Pemerintah daerah harus memastikan bahwa penerimaan pajak lebih tinggi dari biaya pemungutan. Selain itu, pemerintah daerah perlu menjaga stabilitas penerimaan pajak tersebut (Mahmudi, 2012).

Pajak kabupaten/kota terdiri dari: pajak hotel, Pajak restoran, Pajak hiburan, Pajak reklame, Pajak penerangan jalan, Pajak pengambilan bahan golongan C, Pajak parkir, Pajak air tanah, Pajak sarang burung walet, Pajak bumi dan bangunan perdesaan dan perkotaan, Pajak bea perolehan hak atas tanah dan bangunan. Berdasarkan sumber-sumber dari pajak daerah sebagian besar sudah dikelola oleh masing-masing kabupaten/kota, sehingga mengakibatkan jumlah pendapatan yang diterima provinsi dari penghasilan pajak daerah menjadi berkurang.

Retribusi daerah adalah pembayaran wajib oleh orang pribadi atau badan atas disediaakannya jasa tertentu oleh pemerintah dan mendapatan timbal balik secara langsung. (Siahaan, 2005:5). Jenis pos retribusi daerah dapat dikelompokan menjadi Retribusi Jasa Umum, Retribusi Jasa Usaha dan Retribusi Perizinan.

Hasil penelitian ini menunjukan bahwa Retribusi Daerah berpengaruh tidak signifikan terhadap Kinerja Keuangan Derah di Provinsi Bali berdasarkan pada Tabel 6. Hal ini sesuai dengan hasil penelitian sebelumnya dari Mukarramah (2017) bahwa retribusi daerah ternyata tidak berpengaruh signifikan terhadap kemandirian keuangan daerah di lima kabupaten/kota Provinsi Jawa Barat Tahun 
2008-2014. Sebagaimana kita ketahui bahwa kemandirian keuangan daerah juga merupakan tolah ukur kinerja keuangan daerah. Demikian juga penelitian Putriani (2016) menunjukkan bahwa retribusi daerah berpengaruh positif namun tidak signifikan terhadap pendapatan asli daerah Kabupaten Bulukumba. Namun hasil penelitian lainnya dari Putri \& Rahayu (2015), pada Pemerintah Daerah Kabupaten Cirebon Tahun Anggaran 2010-2014 menunjukkan bahwa retribusi daerah berpengaruh positif dan signifikan terhadap pendapatan asli daerah.

Terihat bahwa kontribusi Retribusi Daerah terhadap Pendapatan Asli Daerah masih sangat kecil dikarenakan porsi retribusi daerah sangat kecil jumlahnya dibandingkan dengan penerimaan pajak daerah. Serta adapun sumbersumber dari retribusi daerah sebagian besar belum masuk dalam pos pendapatan daerah, sehingga mengakibatkan operasional keuangan daerah berkerja secara tidak baik atau optimal. Untuk itu diperlukan optimalisasi sumber-sumber penerimaan PAD untuk mewujudkan kinerja kuangan daerah.

Retribusi daerah menjadi salah satu indikator untuk mengevaluasi serta mengetahui kinerja keuangan pemerintah daerah. Pemerintah daerah diharapkan mampu menggali sumber-sumber kekayaan asli daerah untuk memenuhi kebutuhan pembangunan dan pembiayaan di daerahnya yang tentunya berpengaruh terhadap kinerja keuangan daerah.

Hal ini terjadi dikarenakan masih banyaknya permasalahan retribusi yang sering terjadi di daerah-daerah. Contohnya permasalahan retribusi parkir, bagaimana permasalahan retribusi parkir di tepi jalan umum atau di pasar-pasar tradisional yang sering disalahgunakan oleh oknum yang tidak bertanggungjawab 
untuk meraup untung. Aturan Pemda yang seharusnya dijalankan menjadi tidak berguna, karena mereka para pemungut retribusi yang seharusnya menyetorkan hasil retribusi ke daerah malah digunakan secara pribadi. Sehingga hasil retribusi yang diperoleh tidak sesuai dengan anggaran sehingga mempengaruhi perolehan PAD nya.

Lain-lain Pendapatan Asli Daerah yang Sah merupakan penerimaan daerah yang tidak termasuk dalam jenis pajak daerah, retribusi daerah, dan hasil pengelolaan kekayaan daerah yang dipisahkan. Dalam Pasal 22 Ayat 2 Peraturan Pemerintah Nomor 58 Tahun 2005 tentang pengelolaan keuangan dearah disebutkan bahwa lain-lain PAD yang sah mencakup: hasil penjualan kekayaan daerah yang tidak dipisahkan; hasil pemanfaatan atau pendayagunaan kekayaan daerah yang tidak di pisahkan; jasa giro; pendapatan bunga; tuntutan ganti rugi; keuntungan selisih nilai tukar rupiah terhadap mata uang asing; komisi; potongan ataupun bentuk lain sebagai akibat dari penjualan dan/atau pengadaan barang dan/atau jasa oleh daerah.

Berdasarkan pada Tabel 9 hasil penelitian ini menunjukan bahwa kontribusi lain-lain pendapatan asli daerah yang sah terhadap Pendapatan Asli Daerah masih sangat kecil. Hasil penelitian ini berbeda dengan penelitian sebelumnya dari Nuzulistyan et al. (2017) bahwa lain-lain pendapatan asli daerah yang sah berpengaruh positif dan signifikan terhadap pendapatan asli daerah Provinsi Jawa Tengah. Demikian halnya dengan hasil penelitian Nurafni (2016) bahwa lain-lain pendapatan asli daerah yang sah berpengaruh positif dan signifikan terhadap pendapatan asli daerah Kota Padang. Perbedaan ini 
disebabkan karena perbedaan lokus penelitian, dimana Provinsi Jawa Tengah memiliki APBD yang jauh lebih besar dari Provinsi Bali, serta wilayah maupun jumlah penduduk yang lebih tinggi. Penerimaan Dana Alokasi Umum (DAU) yang diperoleh Pemerintah Provinsi Bali dari pemerintah pusat masih lebih kecil dibandingkan dari DAU dari Provinsi lainnya, mengakibatkan biaya untuk pembangunan diambil dari pos anggaran lain.

\section{SIMPULAN}

Pajak Daerah berpengaruh tidak signifikan terhadap Kinerja Keuangan Daerah di Pemerintahan Kabupaten/Kota Provinsi Bali tahun 2012-2016. Retribusi Daerah berpengaruh tidak signifikan terhadap Kinerja Keuangan Daerah di Pemerintahan Kabupaten/Kota Provinsi Bali tahun 2012-2016. Lain-lain pendapatan daerah yang sah tidak signifikan berpengaruh terhadap Kinerja Keuangan Daerah di Pemerintahan Kabupaten/Kota Provinsi Bali tahun 2012-2016.

Berdasarkan hasil penelitian selanjutnya diharapkan mampu mendorong peneliti-peneliti selanjutnya untuk mengamati faktor-faktor lain yang dapat mempengaruhi pajak daerah, retribusi daerah dan pendapatan lain-lain yang sah. Beberapa faktor dimaksud seperti jumlah penduduk, PDRB, pengeluaran pemerintah, dan inflasi. Selain itu, berdasarkan hasil penelitian terlihat bahwa pemerintah, khususnya Pemerintah Provinsi Bali, perlu mengoptimalkan unsurunsur Pendapatan Asli Daerah, baik melalui upaya intensifikasi maupun ekstensifikasi sumber-sumber pendapatan daerah. 


\section{REFERENSI}

Aragon, F. M. (2009). The Flypaper Effect Revisited. Journal Sticerd London Of School Of Economic, 4, 1-14. https://doi.org/10.3386/w14579

Halim, A. (2007). Akuntansi Sektor Publik Akuntansi Keuangan Daerah. Jakarta: Salemba Empat.

Hoque, Z., \& Adams. (2008). Measuring Public Parfomance: A Study Of Government Departements In Australia.

Julitawati, E., Darwanis, \& Jalaluddin. (2012). Pengaruh Pendapatan Asli Daerah (PAD) Dan Dana Perimbangan Terhadap Kinerja Keuangan Pemerintah Kabupaten/Kota Di Provinsi Aceh. Jurnal Akuntansi, 1(1), 15-29. https://doi.org/10.1093/bioinformatics/btu031

Mahmudi. (2012). Manajemen Keuangan Daerah. Jakarta: Erlangga.

Mukarramah, H. (2017). Pengaruh Pajak Daerah dan Retribusi Daerah Terhadap Kemandirian Keuangan Daerah di Lima Kabupaten/Kota Provinsi Jawa Barat Tahun 2008-2014. Universitas Islam Negeri Syarif Hidayatullah.

Norregaard, J. (2013). Taxing Immovable Property: Revenue Potential and Implementation Challenges. IMF Working Paper, 13(129).

Nurafni. (2016). Analisis Pengaruh Penerimaan Pajak Daerah, Retribusi Daerah, Hasil Pengelolaan Kekayaan Milik Daerah yang Dipisahkan dan Lain-lain Pendapatan Asli Daerah yang Sah Terhadap Peningkatan Pendapatan Asli Daerah (PAD) Kota Padang. Universitas Andalas.

Nuzulistyan, K. R., Supriyanto, A., \& Paramita, P. D. (2017). Pengaruh Pajak Daerah, Retribusi Daerah, Hasil Pengelolaan Kekayaan Daerah yang Dipisahkan, dan Lain-lain Pendapatan Daerah yang Sah Terhadap Pendapatan Asli Daerah Provinsi Jawa Tengah (Studi Kasus pada DPPAD Provinsi Jawa Tengah Periode Tahun 2008-2015). Jurnal Ilmiah Mahasiswa S1 Akuntansi Universitas Pandanaran, 3(3).

Poulson, B. W., \& Kaplan, J. G. (2008). State Income Taxes and Economic Growth. Cato Journal, 28(1).

Putri, M. E., \& Rahayu, S. (2015). Pengaruh Pajak Daerah dan Retribusi Daerah Terhadap Pendapatan Asli Daeah (Studi Kasus Pada Pemerintah Daerah Kabupaten Cirebon Tahun Anggaran 2010-2014). E-Proceeding of Management, 2(1), 281-288.

Putriani, E. (2016). Pengaruh Retribusi Daerah Terhadap Pendapatan Asli 
Komang Aryagus Wiguna dan I Ketut Jati. Pengaruh ...

Daerah (PAD) Kabupaten Bulukumba. Universitas Islam Negeri Alauddin.

Siahaan, P. M. (2005). Pajak Daerah dan Retribusi Daerah. Jakarta: PT. Rajagrafindo Persada.

Tjip, I. (2012). Paradigm Change of Local Tax. Journal of Administrative Science and Organization, 18(1), 34-42.

Vamiagustin, V., Suhadak, \& Saifi, M. (2014). Pengaruh Pajak Daerah terhadap Pendapatan Asli Daerah (Studi Kasus pada Dinas Pendapatan Kota Batu Tahun 2010 - 2012). Jurnal Administrasi Bisnis, 14(2), 1-10. 